\title{
LEGISLATION MADE FOUR DECADES AGO ON "SMELLING OF LIQUOR": ERRONEOUS IN THE CONTEXT OF CURRENT SCIENTIFIC KNOWLEDGE
}

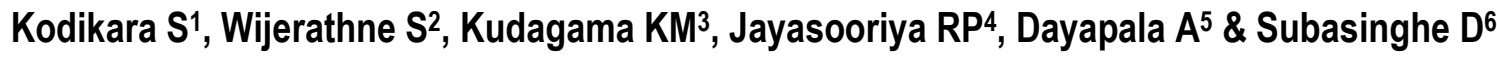

DOI :

http://doi.org/10.4038/sljfmsl.v11 i2.7861

Corresponding Author
Kodikara S
1 Dept. of Forensic Medicine,
Faculty of Medicine,
University of Peradeniya,
Sri Lanka
kaskodikara@yahoo.com
10 https://orcid.org/0000-
0002-3790-0489

${ }^{2}$ Teaching Hospital, Kandy,
Sri Lanka.
${ }^{3}$ Teaching Hospital, Rathnapura,
Sri Lanka.
${ }^{4}$ Base Hospital, Mahiyanganaya,
Sri Lanka.
${ }^{5}$ Base Hospital, Avissawella,
Sri Lanka.
${ }^{6}$ Private Lawyer, Sri Lanka.

Key Words

Ethyl alcohol, smelling, liquor, congener

Article History

Received: 20.05.2020

Received in revised form: 18.09.2020

Accepted: 16.10 .2020

Available online: 21.12 .2020

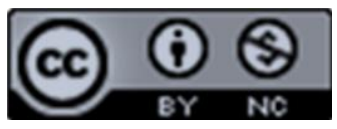

This article is licensed under the terms of the Creative Commons Attribution-Non Commercial 4.0 International License.

e-ISSN: 2465-6089

\section{ABSTRACT}

Science has evolved radically during the last few decades. Therefore, certain legislation made based on the scientific knowledge of a particular era, should be reviewed in the context of new knowledge in the field of science.

Section 11 of the 'Offences committed under the influence of liquor (special provisions) act no. 41 of 1979' states that 'A person shall be presumed to be under the influence of liquor if at or about the time of the commission of the act he is smelling of liquor .... unless evidence to the contrary has been adduced.' An endorsement to the presence of breath smelling of alcohol by the medical expert in the MedicoLegal Examination Form could lead to a conviction under this act.

Ethyl alcohol is almost odourless and its smell is due to the presence of volatile substances called congeners produced simultaneously during the process of fermentation of ethyl alcohol. Therefore, the odour of alcohol frequently detected on people after consumption of alcoholic beverages is not due to alcohol, but to by-products of alcohol manufacture known as congeners.
In addition, this odour may persist in the tissues for several hours even after the alcohol has been eliminated from the body.

Therefore, the legal presumption that alcohol is present in blood, based upon the smell of liquor is erroneous. Conviction upon smelling of liquor should be stopped with immediate effect and the said legislation should be amended. Further, the MedicoLegal Examination Form should also be amended in this regard.

\section{INTRODUCTION}

The smell of liquor is a legally accepted indicator of 'drunkenness' in Sri Lanka. Section 11 of the 'Offences committed under the influence of liquor (special provisions) act no. 41 of 1979' states that 'A person shall be presumed to be under the influence of liquor if at or about the time of the commission of the act he is smelling of liquor .... unless evidence to the contrary has been adduced.' ${ }^{1}$ Accordingly, it is presumed that for the purpose of this act, a person is under influence of alcohol, if he was smelling of liquor at or about the time of commission of act.

In the subsequent interpretation of the same act, it is mentioned that "liquor" includes spirit, wine, toddy, beer, and all liquid consisting of or containing alcohol. $^{2}$ 
Widely consumed alcoholic beverages contain ethyl alcohol. For the purpose of this paper, it is assumed that the term meant by 'alcohol' in the said law is ethyl alcohol.

Upon conviction, the said person shall be liable to be punished with imprisonment of either description for a term of not less than six months, and not exceeding two years, and shall also be liable to a fine of not less than one thousand rupees and not exceeding two thousand five hundred rupees. ${ }^{3}$

Based on this indicator, police seek scientific evidence from medical experts through the Medico-Legal Examination Form (MLEF) on whether a certain person was smelling of liquor which would lead to subsequent prosecution under this law. For this purpose, there is a tick box with 'breath smelling of alcohol' in the MLEF where a medical expert needs to indicate the status. An endorsement to the presence of alcohol smell in the breath by the medical expert in the MLEF could lead to a conviction under this act.

However, does the breath really smell of ethyl alcohol?

Ethyl alcohol is almost odourless and its smell is considered to be due to the presence of volatile substances called congeners, produced simultaneously during the process of fermentation of ethyl alcohol. ${ }^{4}$ Sometimes aromatic congeners are wittingly added to some alcoholic beverages of inferior quality to produce an odour to convince consumers that a particular beverage is of good quality. ${ }^{5}$ These include, acetone, acetaldehyde, esters, tannins, and aldehydes. ${ }^{4}$ Therefore the "odour of alcohol" frequently detected on people after consumption of alcoholic beverages is not due to alcohol but to by-products of alcohol manufacture or congeners. ${ }^{5}$

The smell of an alcoholic beverage can persist in tissues and breath for several hours after all the alcohol has been metabolized or eliminated from the body. ${ }^{5,6}$ A situation has been encountered where an odour of alcohol was detected at autopsy but the blood alcohol levels were negative. ${ }^{5}$ It is also possible that a person who has consumed another beverage containing the said congeners will "smell of alcohol". The reason for this is that the metabolic pathways of degradation of ethyl alcohol and the rest of the congeners are different in the body. Therefore it should be noted that congeners can enter the human body even without consumption of alcohol or be produced naturally in the human body.

Acetone is produced naturally in the human body during ketoacidosis and gives the characteristic alcohol smell in breath. Alcohol free beverages, jams, bread, vegetables, fruits and milk contain Acetaldehyde ${ }^{7}$. Esters are present in commonly consumed fruits and vegetables, such as apples, apricots, mandarins, mangoes, papayas, red and chili peppers, potatoes or squash. ${ }^{8}$ Tannins have been found in a variety of plants utilized as food and feed such as sorghum, millets barley, legumes, dry beans, pomegranates, cranberries, blueberries, hazelnuts, walnuts, pecans, peanuts, chickpea. ${ }^{9}$ Aldehydes are formed endogenously by lipid peroxidation, carbohydrate or metabolism ascorbate autoxidation, amine oxidases, cytochrome P-450s, or myeloperoxidasecatalyzed metabolic activation. ${ }^{10}$ In addition, dietary aldehydes and drugs that are aldehydes or reactive aldehyde metabolites can introduce aldehydes in to the body without consumption of alcohol. ${ }^{10}$

In addition, the said substances are also present as excipient in some herbal medicines and pharmaceutical drugs. ${ }^{11}$ Salicylic acid acetate, or aspirin, is one of many esters used as medicines. Phenyl salicylate, a similar aromatic ester, is used in the treatment of rheumatic arthritis. Methyl phenidate, an ester is used to stimulate the central nervous system. The pharmaceutical industry has discovered that certain undesirable properties of drugs, such as bad taste or swelling of the skin at the spot of an injection, can be avoided by converting the original drug into an ester. The antibiotic clindamycin, a bitter tasting drug, was converted to its palmitate ester in order to make its flavor less harsh. ${ }^{11}$ 


\section{CONCLUSION}

Therefore, the legal presumption that alcohol is present in blood, based upon the "smell of liquor" is erroneous from a scientific and evidence based perspectives. Conviction upon the "smell of liquor" should be stopped with immediate effect and the said legislation should be amended. Further the MLEF should also be amended in this regard.

\section{REFERENCES}

1. Offences committed under the influence of liquor (special provisions) act no. 41 of 1979, Section 11

2. Offences committed under the influence of liquor (special provisions) act no. 41 of 1979, Section 14

3. Offences committed under the influence of liquor (special provisions) act no. 41 of 1979, Section 12

4. Rohsenow DJ, Howland J, Arnedt JT, Almeida $A B$, Greece J, Minsky S, et al. Intoxication with bourbon versus vodka: effects on hangover, sleep, and next-day neurocognitive performance in young adults. Alcoholism: clinical and experimental research [Internet]. 2010; 34(3):[509-18 pp.]. Available from: https://onlinelibrary.wiley.com/doi/full/10.111 1/j.1530-0277.2009.01116.x.

5. Freimuth HC. Forensic aspects of alcohol. In: Spitz WU, editor. Medicolegal investigation of death: Guidelines for the application of pathology to crime investigation. 2nd ed. Springfield: Charles C. Thomas Publisher; 1980. p. 767-75.
6. Vij K. Text book of forensic medicine and toxicology: Principles \& practice. Noida: Elsevier Health Sciences; 2014.

7. Uebelacker M, Lachenmeier DW. Quantitative determination of acetaldehyde in foods using automated digestion with simulated gastric fluid followed by headspace gas chromatography. Journal of automated methods and management in chemistry. 2011. doi:10.1155/2011/907317

8. Bunea A, Socaciu C, Pintea A. Xanthophyll esters in fruits and vegetables. Notulae botanicae horti agrobotanici cluj-napoca. 2014;42(2):310-24. doi:10.15835/nbha4229700

9. Chung K-T, Wong TY, Wei C-I, Huang Y-W, Lin Y. Tannins and human health: a review. Critical reviews in food science and nutrition. 1998;38(6):421-64.

doi:10.1080/10408699891274273

10. O'Brien PJ, Siraki AG, Shangari N. Aldehyde sources, metabolism, molecular toxicity mechanisms, and possible effects on human health. Critical reviews in toxicology. 2005;35(7):609-62. doi:10.1080/10408440591002183

11. Science encyclopedia. Ester. Available from: https://science.jrank.org/pages/2572/Ester.htm I\#: :text=

Salicylic\%20acid\%20acetate\%2C\%20or\%20aspiri $\mathrm{n}$,stimulate\%20the\%20central\%20nervous\%20s ystem[Accessed on 01 Sep 2020] 